\title{
Biomass of Scots pine-silver birch tree stand 25 years after afforestation of former agricultural land
}

\author{
Milosz Deptula, Andrzej Nienartowicz, Marta Iwicka, Anna Filbrandt-Czaja \\ Nicolaus Copernicus University, Faculty of Biology and Environment Protection, Chair of Geobotany \\ and Landscape Planning, Lwowska 1, 87-100 Toruń, Poland, \\ *deptula@umk.pl
}

Received: 25 April 2017/Accepted: 05 June 2017

\begin{abstract}
In 2015, the structure of a forest stand growing on former agricultural land in subunit 277n of the Przymuszewo Forest Division (Regional Directorate of State Forests RDSF in Toruń) was described. The study area was afforested in 1990 - mostly with Scots pine (Pinus sylvestris L.), silver birch (Betula pendula Roth) and several seedlings of the European beech - after many years of agricultural cultivation of grain and potato crops. Characteristics of the forest stand comprised the following parameters: species composition and species diversity, density of individual components, the average tree diameter at breast height (DBH), and the height and aboveground biomass of trees divided into individual species. The species structure, dendrometric characteristics and spatial distribution of trees studied in 2015 were compared with the situation assessed in 2000.

Based on DBH and height values, as well as the use of dendrometric tables and basic wood density for tree species, the aboveground biomass and total biomass of trees with a minimum diameter of $7 \mathrm{~cm}$ were calculated. The aboveground and total biomass for trees with DBH less than $7 \mathrm{~cm}$ was calculated on the basis of density and weight of trees according to the classification into species and height classes. The aboveground and total biomass of the whole tree stand, including spontaneous non-native and invasive Padus serotina Ehrh., was compared with the standing biomass of agricultural areas in the Tuchola Forest region as well as with other Scots pine-silver birch plantations on former agricultural lands described in ecological literature.

The paper presents also the differences in assessments of aboveground pine biomass at the study site obtained when using conversion factors established during direct measurements carried out in forests of the Przymuszewo Forest Division and conversion factors applied during inventories conducted in Poland according to the IPCC recommendations for international reporting submitted to the United Nations Economic Commission for Europe, FAO and UNFCCC.
\end{abstract}

Key words: afforestation, dendrometry, plantation, Padus serotina, post-agricultural lands, species diversity, Tuchola Forest.

\section{Introduction}

The process of forest reconstruction on former agricultural lands is one of the most important economic objectives of forestry, as well as one of the most important and interesting problems of modern ecology. The growing interest in increasing the afforestation rate at the country, regional and global level results from the significant role of forest ecosystems in mitigating the "greenhouse effect" and increasing the ecological balance in the natural environ- ment. One of the initiatives undertaken at the global level is the approach promoted in the documents adopted at the United Nations Conference on Environment and Development ("Earth Summit") in Rio de Janeiro in 1992 calling for efforts towards "greening the world" and programmes developed under the IPPC (IPPC, 1996). The European Union has implemented some legal regulations that create the basis for granting the financial assistance to those Member States who engage in efforts aimed at increasing the forest area through afforestation of uncultivated 
and agriculturally inefficient lands. In Poland, a significant increase in the afforestation rate after World War II was implemented within the scope of three projects: $1-$ a restoration plan for forest ecosystems after World War II devastation, 2 - a national programme to increase the afforestation rate, developed in the 1990s by the Minister of the Environmental Protection, Natural Resources and Forestry, 3 - "the State Forest Policy" adopted by the Council of Ministers in 1997. The objective of the latter initiative is to increase the afforestation rate in the country up to $30 \%$ in 2020 and $33 \%$ in the mid-21st century (Gorzelak, 1999). These objectives are to be implemented mainly through afforestation of unproductive agricultural lands.

In 1946-1994, ca. 1.200 thousand ha of previously cultivated or uncultivated lands were afforested across Poland (Wójcik, 1996). The preferred species at that time was Scots pine, less frequently silver birch, Norway spruce and other species. The consequence of such actions are monospecies forest stands of the same age developed over relatively large areas, which are exposed to many destructive factors, i.e. annosum root rot (Heterobasion annosum (Fr.) Bref.), gradations of insects or fire. These factors cause major losses in the growth of trees and forest area and, consequently, losses in the production of wood. On the other hand, despite the impact of unfavourable factors and compared to the previously existing agroecosystems, forests reconstructed on former arable lands are systems with a high carbon content accumulated in the living plant biomass and in the soil of the forest ecosystem.

The importance of ecological effects of afforestation and problems encountered during the implementation of this process resulted in the increasing number of studies that relate to the forest development on former agricultural lands. The establishment success of plantations, their resistance to pests and adverse abiotic factors, the biomass growth of trees as well as the species diversity of forest stands and the whole forest ecosystem are particularly thoroughly researched.

The issue of afforestation on former agricultural lands in Poland has been studied i.e. by Bernadzki and Kowalski (1983), Bernadzki (1990), Niziński (1990), Rykowski (1990), Sobczak (1996), Szujecki (1990), Tuszyński (1990), Gorzelak (1999). Research on former agricultural lands was also carried out in other EU and non-EU countries, the results of which have been published in a number of papers and books (e.g. Salbitano, 1988; Watkins, 1993; Johnston et al., 1996; Johansson, 1999, 2007; Flinn \& Vellend, 2005; Heil et al., 2007; Kirkby \& Watkins, 2008; Muys et al., 1992; Uri el al., 2002, 2007; Bardulis et al., 2015). Some of the interesting aspects, studied include changes in the species composition, changes in the productivity of trees, and development of forests on former agricultural lands, which prompts to further, more profound analysis of the impact exerted on these processes by substances contained in ag- ricultural soils. In the circumstances when urgent measures aimed at mitigating the greenhouse effect are required, the most important issue is to assess the environmental effect of afforestation of fallow lands, which is manifested in the increased plant biomass and amounts of organic carbon accumulated in that biomass, observed at different levels of biosphere organization - from an individual and a population of trees to a landscape and region.

Pomerania is one of the regions in Poland with the highest contribution of forests restored on former farmlands. In this region, there are many secondary forest areas resulting from intensive afforestation carried out after previous extensive deforestation. Deforestation of the region was carried out from the 16th century to the late 19th century, since when intensive afforestation was undertaken by the Prussian authorities and continued by the Polish foresters after 1920. There are many forests on former farmlands in the region of Pomerania, including mainly the Przymuszewo Forest Division, which belongs to RDSF in Toruń. Until 1920, the area of today's Przymuszewo Forest Division belonged to the Prussian Zwanshoff Forest District, which was established in 1890 on the grounds of former Prussian estates as well as the Polish ones purchased or taken over by the Prussian government as part of the "Kulturkampf" policy and intended for afforestation. Further intensive afforestation took place after World War I, when the area of Gdańsk Pomerania was included in the Polish forest district established in this area. The next major afforestation of former agricultural lands was carried out after World War II when large estates were nationalized and incorporated into the State Forests management as part of the so-called agrarian reform. The last major afforestation in the Przymuszewo Forest Division took place in the 1990s due to the lack of profitability of agriculture in small areas within forests on poor sandy soils, and as a result of demographic processes, such as aging of farmers, migration of successors and users of agricultural lands to the cities. They relinquished their lease and the owner of the land, i.e. the state forest administration afforested the fallow lands.

Changes in the range of forests occurring in the Przymuszewo Forest Division in the period of 1874-2004 were described by Wilkoń-Michalska et al. (1999), Nienartowicz et al. (2002) and Deptuła (2004, 2006). The latter of the above authors assessed the changes in the plant biomass and the amount of carbon contained in that biomass on a map sheet at a scale of 1: 25000, covering an area of about $120 \mathrm{~km}^{2}$. Nienartowicz et al. $(1998,2015)$ assessed the biomass changes resulting from afforestation of a landed estate covering 612 ha, where heaths used for sheep and cattle grazing dominated before the afforestation.

The objective of this work was to present the effects of afforestation on the accumulation of plant biomass and carbon contained in this biomass based on the example of 
one formerly arable plot in the Przymuszewo Forest Division afforested in 1991. In 2000, all trees still growing on this permanent study plot after nine years of cultivation were measured (Dykiert, 2000). In 2015, measurements of all trees in the forest stand growing at the same plot were repeated. This paper presents a comparison of dendrometric features of the forest stand between 2000 and 2015 and described a range of changes occurring in its structure over the period of 15 years. Dendrometric parameters and the determined differences were examined in terms of ecological problems described in the literature as those encountered in the process of forest reconstruction on former arable lands. The main objective of our study was to answer the following three questions: 1) What is the standing crop after 25 years since afforestation of the fallow land? 2) To what extent this biomass is greater compared to the field and the fallow land before afforestation? 3) What are the differences between assessments of the pine biomass with the use of conversion factors established mainly by direct measurements carried out in the Przymuszewo Forest Division and conversion factors used in inventories carried out in Poland according to the IPCC recommendations for international reporting submitted to the United Nations Economic Commission for Europe, FAO and UNFCCC?

\section{The study area}

The research was conducted in subunit 277n of the Przymuszewo Forest Division, which is the northernmost economic unit of RDSF in Torun (Fig. 1). In terms of the territorial administration, the study area and the whole forest district are located in the Pomerania province, the Chojnice county (powiat) and the Brusy commune. According to the nature and forest regionalization proposed by Trampler et al. (1990), the Przymuszewo Forest Division belongs to the Wielkopolska-Kujawy (III) natural-forest

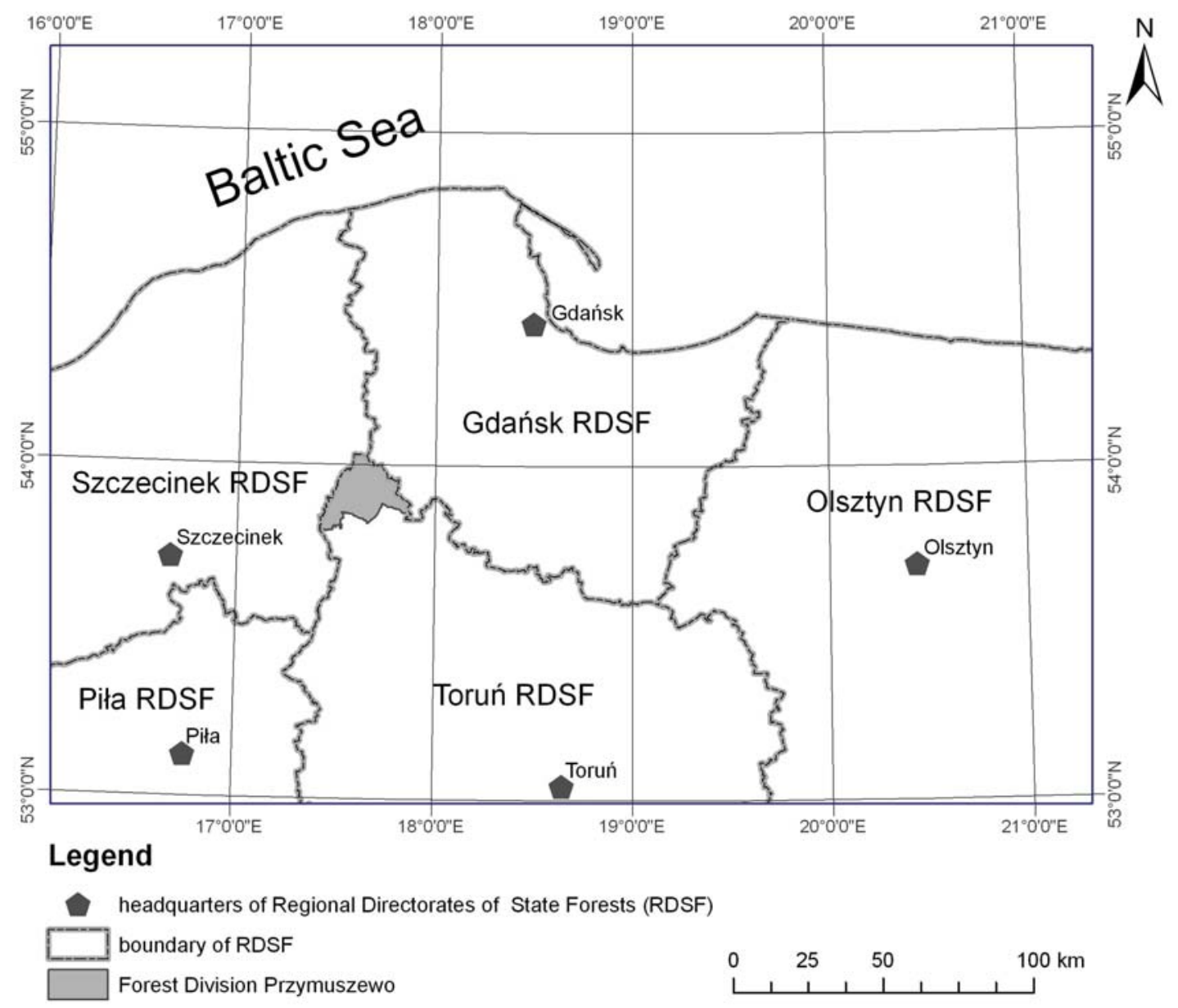

Figure 1. Location of Przymuszewo Forest Division in Northern Poland 
region and the Tuchola Forest district. In the system of protected areas, the study area is located in the Zaborski Landscape Park, and in the Special Area of Conservation PLH 220026 Wielki Sandr Brdy and the Special Protection Area of Birds PLB 220009 Bory Tucholskie. The area is also adjacent to the nature reserve Kulawa Valley (Dolina Kulawy) and the Tuchola Forest Biosphere Reserve. The study area is located in the vicinity of the Laska forest village on the slope with $\mathrm{N}-\mathrm{E}$ exposure descending gently towards Lake Sieczonek (Fig. 2). The lake was formed in the place where the small Kulawa river flows into the Zbrzyca river, which is a tributary of the Brda River, i.e. one of the main rivers in the Tuchola Forest region (Choiński, 2002). The area is bordered by a narrow strip of slightly younger pine woods adjacent to the lower-lying reed beds at the lake.

In the south-west and in the north, the study area is surrounded by pine forest growing in the upper part of the slope. A small number of Picea abies (L.) H. Karst, Betula pendula L., Quercus robur L. and Fagus sylvatica L. occurred locally in the main tree stand. According to the State Forest Management Plan for the Przymuszewo Forest Division (Plan Urządzania Gospodarstwa Leśnego..., 1999), the site index class of this tree stand was Ia,5 in 1999 and the trees were then 46 years old, thus in 2015 (i.e. 16 years later, at the time of our studies) they were 62 years old. The banks of the Kulawa river near the study area are overgrown with alluvial alder forest, while the banks of the Zbrzyca river - with black alder and Norway maple trees.

The study area is an elongated rectangle of $117 \times 27 \mathrm{~m}$ (0.3159 ha). Until the mid-1980s, the area was used as part of the lease by a worker of the Przymuszewo Forest Division. Rye and potatoes were cultivated alternately in the area. For 4 years before the afforestation, the area was a fallow land. In 1990, the study area was afforested mainly by Scots pine and silver birch. The pine was planted in

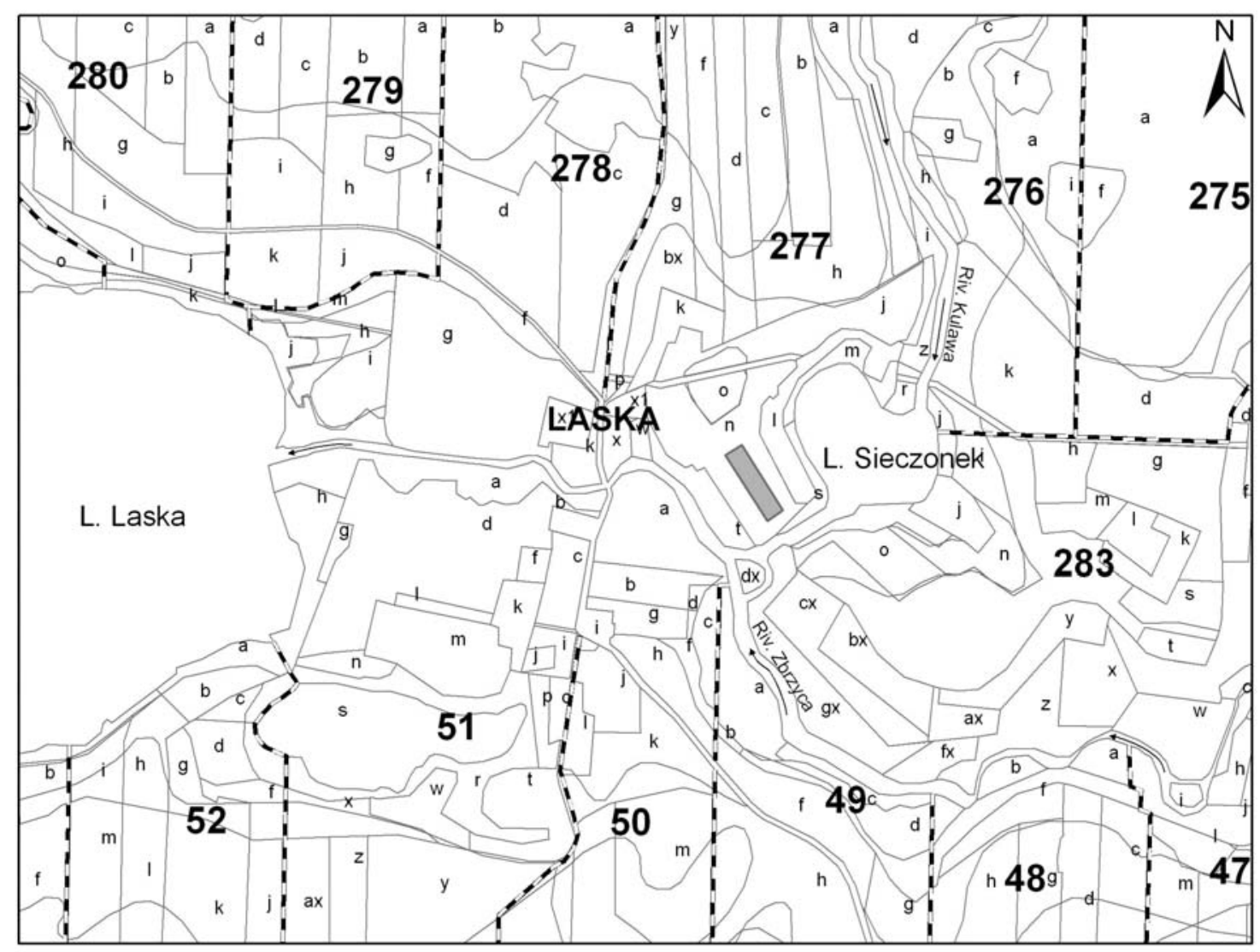

\section{Legend}


Figure 2. Location of the study area (subunit 277n) in Przymuszewo Forest Division 
the central part of the study area, and the birch - along longer sides of the area, in five rows on each side, as well as at its northern edge. In one of the extreme rows of birch, a few dozen beech trees were planted along a small section. Based on the distribution maps of trees, it has been found that Scots pine occurs over an area of 0.1994 ha, whereas silver birch over an area of 0.1165 ha. Apart from Scots pine and silver birch, the black cherry was noted in the upper tree layer of the study area. The age of the main forest stand was 25 years. Scots pine, silver birch, grey alder, Norway spruce, common juniper, common rowan, black cherry, European beech, Norway maple and pedunculate oak occur in the groundcover and in the undergrowth. In the herb layer, Deschampsia flexuosa L., Festuca ovina L., Corynephorus canescens L. and mosses - Pleurozium schreberi (Willd.) Mitten., Dicranum undulatum Schrad., Pohlia nutans (Hedw.) Lidb. are the dominant species.

\section{Materials and methods}

The location of each tree and shrub, including both individuals in the main stand and in the understorey as well as seedlings growing in the herb layer was determined over the whole area using two measuring tapes. While moving along the rows of trees, $\mathrm{x}$ and $\mathrm{y}$ coordinates of each of them (identified to the species level), height and diameter at breast height were determined. The height of trees belonging to the main stand (overstorey) was measured using the device Suunto PM-5/1520. The height of younger specimens belonging to the lower forest layers was determined using a pole. These specimens were classified into height classes every $0.5 \mathrm{~m}$. DBH was determined using a 40 $\mathrm{cm}$ calliper. Tree diameter at breast height (including the thickness of a bark) was determined to the nearest $0.5 \mathrm{~cm}$. After conducting field observations and measurements, the composition of tree species occurring in the study area in 2015 was compared with that of 2000, described by Dykiert (2000). The species composition and the number of trees by species were compared and indicators of species diversity and evenness were calculated using MVSP (Kovach, 1993).

Based on dendrometric measurements for each Scots pine, silver birch and black cherry with a breast height diameter of at least $7 \mathrm{~cm}$, the volume of the aerial parts was determined using tables of Czuraj (1991). For the few specimens of black cherry, for which no tables of thickness were available, abundance tables for birch were used according to the Forest Management Instruction (part 1, Instruction on how to prepare a forest management plan for a forest division, Annex to Ordinance no. 43 of the Director-General of the State Forests of 18 April 2003, Warsaw 2003). Next, the value of volume for each tree was multiplied by the specific gravity of wood (wood density) used in the Poland's National Inventory Report (KOBiZE 2013 after Jabłoński \& Budniak, 2014). The value was 0.43 for Scots pine and 0.52 grams dry matter $/ \mathrm{cm}^{3}$ for silver birch. For black cherry, the value of 0.55 grams dry matter $/ \mathrm{cm}^{3}$ was adopted (Kozakiewicz, 2010). The biomass of trees with a breast height diameter of at least $7 \mathrm{~cm}$ was summed up by species.

Trees with breast height diameter less than $7.0 \mathrm{~cm}$ and juniper bushes were classified into established classes according to their height. The frequency in each height class was calculated for each species. The frequency was multiplied by the average aboveground dry biomass per tree or shrub in a height class. The average biomass of one individual was obtained after cutting trees in the study area or adjacent area. Trees were dried at $80^{\circ} \mathrm{C}$ for 48 hours. In the analysis, we also used the results of our previous studies of the primary production and the biomass of forest stands of different age classes in the Przymuszewo Forest Division (Deptuła, 2004; Jarzębski et al., 2010). The underground biomass and the total dry biomass of all species of trees in this category were calculated using the conversion factors R/S defining the relationship between underground and aboveground biomass of trees for the younger age classes, obtained in the previous studies (Barcikowski \& Loro, 2005; Deptuła, 2006). The relevant fractions of biomass of trees with a breast height diameter below 7.0 $\mathrm{cm}$ were added to the relevant values for trees with a larger breast height diameter. The results are presented for the entire area and for 1 ha. The groundcover biomass value of $0.2384 \mathrm{~kg} / \mathrm{m}^{2}$ (i.e. $2.384 \mathrm{t} / \mathrm{ha}$, including $2.004 \mathrm{t} / \mathrm{ha}$ of above-ground and $0.38 \mathrm{t} / \mathrm{ha}$ of under-ground biomass, respectively) in age class II (21-40 years) forests on former arable lands was added to the values calculated for trees, determined in our previous studies conducted in the vicinity of Laska village at the study sites representing the same category of habitat.

The biomass of the forest phase at the study site was also compared with the biomass of grain crop fields located in the forest and on fallow lands near the village of Laska assessed in our previous studies (Nienartowicz et al., 1998, 2002; Deptuła, 2004).

\section{Results}

\subsection{Species composition and dendrometric characteristics of the forest stand}

A total of 905 trees belonging to 9 species and one species of shrubs - Juniperus communis L., represented by 9 specimens, were recorded in the study area. Compared to 2000 when the total number of trees amounted to 2140 , the number of trees decreased more than twice, while the number of species doubled from 5 to 10 . The species diversity index calculated by the Shannon formula increased 
from 0.894 in 2000 to 1.235 in 2015, whereas the index of species evenness slightly decreased (Table 1). The decline in the number of saplings was mainly due to the early cutting and intraspecific and interspecific competition of plants, game browsing and death of seedlings. Whereas the increase in the number of tree and shrub species resulted from the import of their diaspores from the surroundings.

The comparison of species composition indicates that three species dominated in both phases of the phytocoenosis development, i.e. Scots pine (Pinus sylvestris), silver birch (Betula pendula) and black cherry (Padus serotina). The number of the most abundant species, i.e. Scots pine, decreased more than twice, from 1.178 in 2000 to 499 individuals in 2015. The maximum height of this species increased in that period from $4.0 \mathrm{~m}$ to $21.0 \mathrm{~m}$ (Table 1).

The maximum height of birch changed in a similar range (from 4.0 to $22.0 \mathrm{~m}$ ), but the number of specimens decreased almost five times (from 847 to 175). The contribution of the two additional species, i.e. common rowan (Sorbus aucuparia L.) and grey alder (Alnus incana (L.) Moench) significantly decreased in both compared phas-

Table 1. Comparison of the number of trees and their average height according to the state of the study area in 2000 and in 2015

\begin{tabular}{|c|c|c|c|c|}
\hline Year & \multicolumn{2}{|c|}{2000} & \multicolumn{2}{|c|}{2015} \\
\hline Species & $\begin{array}{l}\text { Number } \\
\text { of trees }\end{array}$ & $\begin{array}{c}\text { Maksimal } \\
\text { height }\end{array}$ & $\begin{array}{c}\text { Number } \\
\text { of trees }\end{array}$ & \begin{tabular}{|c|}
$\begin{array}{c}\text { Maksimal } \\
\text { height } \\
(\mathrm{m})\end{array}$ \\
\end{tabular} \\
\hline Scots pine - Pinus sylvestris L. & 1178 & 4.0 & 499 & 21.0 \\
\hline Silver birch - Betula pendula Roth & 847 & 4.0 & 175 & 22.0 \\
\hline $\begin{array}{l}\text { American black cherry - Prunus serotina } \\
\text { (Ehrh.) Borkh. }\end{array}$ & 82 & 2.0 & 161 & 11.0 \\
\hline European beech - Fagus sylvatica L. & & & 62 & 1.5 \\
\hline Common juniper - Juniperus communis L. & & & 9 & 1.5 \\
\hline $\begin{array}{l}\text { Mountain ash - Sorbus aucuparia L. emend } \\
\text { Hedl. }\end{array}$ & 10 & 0.5 & 3 & 6.0 \\
\hline Norway maple - Acer platanoides $\mathrm{L}$. & & & 2 & 0.5 \\
\hline Grey alder - Alnus incana (L.) Moench & 23 & 0.5 & 1 & 3.0 \\
\hline Pedunculate oak - Quercus robur $\mathrm{L}$. & & & 1 & 0.5 \\
\hline Norway spruce - Picea abies (L.) H. Karst. & & & 1 & 0.5 \\
\hline Total number of trees & 2140 & & 914 & \\
\hline Number of species & 5 & & 10 & \\
\hline Species diversity H' & 0.894 & & 1.235 & \\
\hline Evenness e & 0.556 & & 0.537 & \\
\hline
\end{tabular}


es (Table 1). New species in 2015 (as compared to 2000) were beech (Fagus sylvatica), Norway maple (Acer platanoides L.), common oak (Quercus robur), Norway spruce (Picea abies) and common juniper (Juniperus communis). Fagus sylvatica - represented by a relatively large number of specimens (62) - was introduced in the process of afforestation. The other four species (three tree species and one shrub species) probably came from self-seeding. Three species of trees - maple, oak and spruce were represented by only one specimen.

Table 2 presents the abundance of 10 species determined in 2015 - 914 specimens per DBH classes. It appears that only three species of trees, i.e. Scots pine, silver birch and black cherry reached DBH of $7.0 \mathrm{~cm}$ or more 604 trees in total. The remaining 310 trees had DBH below $7.0 \mathrm{~cm}$. They belonged to all ten species.

In the group of the three most abundant species, 16 pine trees, 57 silver birch trees and only three black cherry trees had DBH below $7.0 \mathrm{~cm}$. The vast majority of individuals of the latter species occurred in the form of several-year-old seedlings and their diameter at breast height was below $3.5 \mathrm{~cm}$. All specimens of the common juniper and almost all trees of the six other species, except for one specimen of the common rowan, occurred in the lowest DBH class.

Scots pine was characterised by the highest variability in DBH. Its specimens occurred in as many as ten defined DBH classes. DBH of the thickest tree in the entire analysed population was in the class of $31.5-34.9 \mathrm{~cm}$. Birch occurred in six DBH classes. The largest number of trees of this species were in the class of 7.0-10.4 cm (Table 2).

The number of three species of trees with DBH above $7.0 \mathrm{~cm}$ and their dendrometric characteristics are presented in Table 3. The volume of aerial parts of 604 trees representing the three species with a DBH of at least $7.0 \mathrm{~cm}$ was $91.75 \mathrm{~m}^{3}$, calculated with the use of Czuraj's (1991) tables. The volume of 499 pine trees, 118 birch trees and 3 black cherry trees was $80.57 \mathrm{~m}^{3}, 11.03 \mathrm{~m}^{3}$ and $0.15 \mathrm{~m}^{3}$, respectively. The volume of pine accounted for almost $88 \%$ of the total volume (Table 3).

Only trees of the three most abundant tree species with DBH values below $7.0 \mathrm{~cm}$ reached great heights (Table 4). The height of Scots pine and black cherry trees was $10.0 \mathrm{~m}$. Most of the trees representing the latter species with small DBH values were included in the lowest height class. This relation also applies to relatively common beech trees and almost all species represented by a small number of individuals. Rowan is an exception in this case, as two specimens of this species reach the height of $5.0 \mathrm{~m}$ and one $6.0 \mathrm{~m}$, while their DBH does not exceed $4.0 \mathrm{~cm}$ (Table 4).

\subsection{Aboveground plant biomass in $\mathbf{2 0 1 5}$}

The aboveground biomass of 483 Scots pine trees with DBH above $7.0 \mathrm{~cm}$ was $37.868 \mathrm{t}$, the biomass of underground parts of pine trees with the same DBH was $8.422 \mathrm{t}$, and the total aboveground and underground biomass was $46.290 \mathrm{t}$ (Table 5A). The aboveground biomass of silver birch with $\mathrm{DBH}$ of at least $7.0 \mathrm{~cm}$ was $5.736 \mathrm{t}$. The bio-

Table 2. The number of trees of 10 species by DBH classes in 2015

\begin{tabular}{|c|c|c|c|c|c|c|c|c|c|}
\hline $\begin{array}{l}\text { DBH class } \\
\text { (cm) }\end{array}$ & $\begin{array}{c}\text { Pinus } \\
\text { sylvestris }\end{array}$ & $\begin{array}{c}\text { Betula } \\
\text { pendula }\end{array}$ & $\begin{array}{c}\text { Padus } \\
\text { serotina }\end{array}$ & $\begin{array}{c}\text { Fagus } \\
\text { sylvatica }\end{array}$ & $\begin{array}{l}\text { Juniperus } \\
\text { communis }\end{array}$ & $\begin{array}{c}\text { Sorbus } \\
\text { aucuparia }\end{array}$ & $\begin{array}{c}\text { Acer } \\
\text { platanoides }\end{array}$ & $\begin{array}{l}\text { Alnus } \\
\text { incana }\end{array}$ & $\begin{array}{c}\text { Quercus } \\
\text { robur }\end{array}$ \\
\hline $0.1-3.4$ & 6 & 24 & 152 & 62 & 9 & 2 & 2 & 1 & 1 \\
\hline $3.5-6.9$ & 10 & 33 & 6 & & & 1 & & & \\
\hline $7.0-10.4$ & 112 & 52 & 2 & & & & & & \\
\hline $10.5-13.9$ & 160 & 29 & & & & & & & \\
\hline $14.0-17.4$ & 126 & 30 & 1 & & & & & & \\
\hline $17.5-20.9$ & 51 & 7 & & & & & & & \\
\hline $21.0-24.4$ & 19 & & & & & & & & \\
\hline $24.5-27.9$ & 4 & & & & & & & & \\
\hline $28.0-31.4$ & 10 & & & & & & & & \\
\hline $31.5-34.9$ & 1 & & & & & & & & \\
\hline Total & 499 & 175 & 161 & 62 & 9 & 3 & 2 & 1 & 1 \\
\hline
\end{tabular}


Table 3. Dendrometric characteristics and the stand volume of the aboveground parts of trees with DBH $\geq 7 \mathrm{~cm}$ by species

\begin{tabular}{|c|c|c|c|c|c|}
\hline \multirow{2}{*}{ Species } & \multirow{2}{*}{$\begin{array}{c}\text { Number } \\
\text { of trees }\end{array}$} & \multirow{2}{*}{$\begin{array}{c}\text { Average } \\
\text { DBH } \\
(\mathrm{cm})\end{array}$} & \multirow{2}{*}{$\begin{array}{c}\text { Average } \\
\text { height } \\
\text { (m) }\end{array}$} & \multicolumn{2}{|c|}{ Stand volume } \\
\hline & & & & $\left(\mathbf{m}^{3}\right)$ & $(\%)$ \\
\hline Pinus sylvestris & 483 & 13.75 & 13.18 & 80.57 & 87.82 \\
\hline Betula pendula & 118 & 11.54 & 12.27 & 11.03 & 12.02 \\
\hline Prunus serotina & 3 & 10.67 & 7.33 & 0.15 & 0.16 \\
\hline Total & 604 & & & 91.75 & 100.00 \\
\hline
\end{tabular}

Table 4. The number of trees of 10 species with $\mathrm{DBH}<7 \mathrm{~cm}$ in subsequent classes of height and the maximum DBH in individual species

\begin{tabular}{|c|c|c|c|c|c|c|c|c|c|c|c|}
\hline $\begin{array}{l}\text { Height class } \\
\text { (m) }\end{array}$ & $\begin{array}{c}\text { Pinus } \\
\text { sylvestris }\end{array}$ & $\begin{array}{c}\text { Betula } \\
\text { pendula }\end{array}$ & $\begin{array}{c}\text { Padus } \\
\text { serotina }\end{array}$ & $\begin{array}{c}\text { Fagus } \\
\text { sylvatica }\end{array}$ & $\begin{array}{l}\text { Juniperus } \\
\text { communis }\end{array}$ & $\begin{array}{c}\text { Sorbus } \\
\text { aucuparia }\end{array}$ & $\begin{array}{c}\text { Acer } \\
\text { platanoides }\end{array}$ & $\begin{array}{c}\text { Quercus } \\
\text { robur }\end{array}$ & $\begin{array}{l}\text { Picea } \\
\text { abies }\end{array}$ & $\begin{array}{l}\text { Alnus } \\
\text { incana }\end{array}$ & $\begin{array}{c}\text { Total } \\
\text { number } \\
\text { of } \\
\text { trees }\end{array}$ \\
\hline $0.01-0.50$ & 4 & & 96 & 51 & 7 & & 2 & 1 & 1 & & 162 \\
\hline $0.51-1.00$ & 1 & 1 & 11 & 10 & 1 & & & & & & 24 \\
\hline $1.01-1.50$ & & 3 & 39 & 1 & 1 & & & & & & 44 \\
\hline $1.51-2.00$ & & 6 & 4 & & & & & & & & 10 \\
\hline $2.01-2.50$ & & 1 & 1 & & & & & & & & 2 \\
\hline $2.51-3.00$ & 1 & 8 & & & & & & & & 1 & 10 \\
\hline $3.51-4.00$ & & 7 & 1 & & & & & & & & 8 \\
\hline $4.51-5.00$ & 2 & 9 & 3 & & & 2 & & & & & 16 \\
\hline $5.51-6.00$ & & 11 & 1 & & & 1 & & & & & 13 \\
\hline $6.51-7.00$ & 3 & 6 & 1 & & & & & & & & 10 \\
\hline $7.51-8.00$ & 4 & 4 & & & & & & & & & 8 \\
\hline $8.51-9.00$ & & 1 & & & & & & & & & 1 \\
\hline $9.51-10.00$ & 1 & & 1 & & & & & & & & 2 \\
\hline Total & 16 & 57 & 158 & 62 & 9 & 3 & 2 & 1 & 1 & 1 & 310 \\
\hline $\begin{array}{l}\text { Max. DBH } \\
(\mathrm{cm})\end{array}$ & 6.5 & 6.0 & 6.5 & 1.0 & 1.0 & 4.0 & 0.5 & 0.5 & 1.0 & 1.5 & \\
\hline
\end{tabular}

mass of underground parts was assessed at $1.451 \mathrm{t}$ and the total aboveground and underground biomass of birch with the same DBH - at $7.187 \mathrm{t}$. In the case of three black cherry specimens, the biomass of aboveground and underground parts as well as of the whole trees amounted to $0.071 \mathrm{t}$, $0.018 \mathrm{t}$ and $0.089 \mathrm{t}$, respectively (Table $5 \mathrm{~A}$ ).

The total aboveground and underground biomass of the three species represented by trees with $\mathrm{DBH}$ of at least
$7.0 \mathrm{~cm}$ was $53.566 \mathrm{t}$, while the contribution of individual components to the total biomass was as follows: $86.417 \%$ for pine, $13.417 \%$ for birch and $0.166 \%$ for black cherry.

The total aboveground biomass of all 310 trees with DBH below $7.0 \mathrm{~cm}$ was $0.316 \mathrm{t}$ (Table 5B). The biomass of underground parts was $0.074 \mathrm{t}$, which amounted to 0.390 $t$ for the entire study area. The biomass of these trees con- 


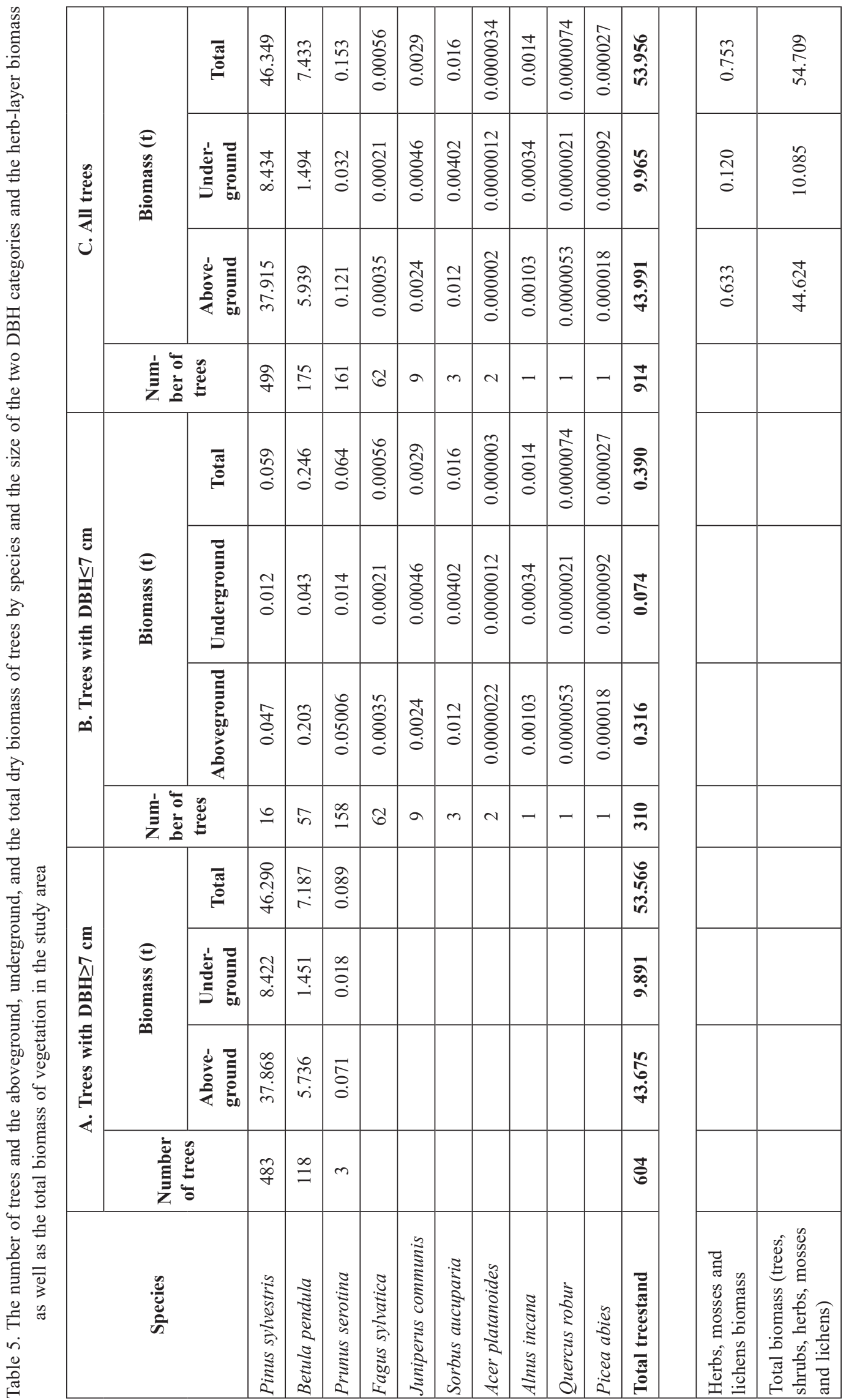


sisted mainly of silver birch $-63.120 \%$, wild black cherry $-16.376 \%$ and Scots pine $-15.142 \%$. Common rowan contributed in only $4.189 \%$, while each of the remaining species - no more than $1 \%$, in total $-1.173 \%$. Contribution of all trees with $\mathrm{DBH}$ below $7 \mathrm{~cm}$ in aboveground biomass of the tree stand was only $0.72 \%$. The total aboveground biomass of all 914 trees growing at the study site - i.e. those with a diameter at breast height below 7.0 $\mathrm{cm}$ and those with a larger DBH - was $43.991 \mathrm{t}$ (Table 5C). The biomass of underground parts was assessed at $9.965 \mathrm{t}$. The total biomass of trees, i.e. aerial and underground parts was $53.956 \mathrm{t}$ (Table 5C). Pine contributed to the total biomass of all trees in $85.901 \%$, birch in only $13.776 \%$, and black cherry - in $0.283 \%$, seven other species $-0.038 \%$ in total.

After conversion to 1 ha unit area, the aboveground biomass of the forest stand was $139.256 \mathrm{t} / \mathrm{ha}$, the underground biomass $-31.545 \mathrm{t} / \mathrm{ha}$ and aboveground and underground biomass in total $-170.801 \mathrm{t} / \mathrm{ha}$.

When taking into account the aboveground and underground biomass of the groundcover in the total biomass of the forest stand, i.e. $2.004 \mathrm{t} / \mathrm{ha}$ and $0.38 \mathrm{t} /$ ha respectively $(0.633 \mathrm{t}$ and $0.12 \mathrm{t}$ for the whole study area of $0.3159 \mathrm{ha})$, we arrived at the value of $54.709 \mathrm{t}$ for the whole study area (Table 5C). Trees with DBH of at least $7.0 \mathrm{~cm}$, trees with DBH below $7.0 \mathrm{~cm}$ and groundcover contributed to this biomass in $97.911 \%, 0.713 \%$ and $1.376 \%$, respectively. After conversion to 1 ha unit area, the total plant biomass (comprising trees, herbs, mosses and lichens) was $173.184 \mathrm{t} / \mathrm{ha}$.

\section{Discussion and conclusions}

Directions of changes in the phytocoenosis structure observed in the study area are similar to those observed in other forest communities developed on former agricultural lands. They include an increase in the number of tree species due to natural spread of diaspores from neighbouring phytocoenoses. A typical phenomenon is also a decrease in the density of planted trees, both due to the competition and the effect of parasites, especially annosum root rot. Such interactions are manifested in fallen trees, considerable gaps in the forest canopy and relatively rapid change in the type of spatial distribution of trees from regular to rather random distribution.

The observations also proved the invasive nature of $\mathrm{Pa}$ dus serotina, which is reflected in the presence of many seedlings. Perhaps they germinated from the seeds of the three older living trees. These trees spread at the study site most likely before afforestation, i.e. at the time when the land was left fallow. They were left in the process of afforestation to increase the species diversity of the forest stand.

Padus serotina was the most common species among trees with DBH below $7 \mathrm{~cm}$. In terms of biomass, black cherry was the second most abundant species after silver birch in this group (category) of trees. Our study determined that the contribution of trees with $\mathrm{DBH}$ below $7 \mathrm{~cm}$ in the total aboveground biomass of the whole tree stand was $0.72 \%$. A slightly higher percentage contribution of the understory and undergrowth in aboveground biomass was reported by Orzeł et al. (2006b) in the oak tree stands in the Niepołomice Forest. In the alder forest stand of the Forest, this contribution was slightly above 2\% (Orzeł et al., 2005). The lower contribution (estimated by us at only $0.72 \%$ ) could result from the fact that the pine-birch forest stand in the Tuchola Forest was younger than the one in the Niepołomice Forest, and the younger development phase is characterised by stronger competition of the main tree stand in relation to the understory and undergrowth.

Czuraj's (1991) tables were used in the assessment of aboveground biomass of trees with DBH above $7.0 \mathrm{~cm}$. The tables provide information on the overall volume of standing trees (in $\mathrm{m}^{3}$ ) as a total value for large timber, i.e. the fraction subject to inventories and parts of the trunk with a diameter below $7.0 \mathrm{~cm}$. Values read from the tables of Czuraj (1991) were converted to dry matter using specific wood density of a given tree species. However, in inventories conducted by the State Forests and reporting to the UN Economic Commission for Europe FAO for 2000 (Temperate and Boreal Forest Resources Assessment - TBFRA-2000), the Biomass Expansion Factor (BEF) is used, i.e. the ratio of the total aboveground biomass of trees to the biomass of large (merchantable) timber according to Szymkiewicz's tables (2001).

According to Jabłoński and Budniak (2014), the ratio for coniferous forest stands in age class II is 1.67 and for over 140-year-old forest stands -1.10 , and the generalized index for coniferous species in total is 1.265 and for deciduous species -1.170 . In ecology, this index was also described as a Total/Merchantable timber (T/M) ratio (Johnson \& Sharpe, 1983; Murillo-Rodriques, 1994, 1997). It is calculated as a ratio of the total aboveground biomass (including the trunk, branches and leaves) to the inventoried biomass of merchantable timber. Based on the direct measurements conducted in our previous studies, we calculated that the $\mathrm{T} / \mathrm{M}$ ratio for Scots pine in age class II was $1.40 \pm 0.13$ and for Scots pine in class V $-1.27 \pm 0.028$ (Deptuła, 2006). When using the T/M index equal to 1.40 and wood density of $0.430 \mathrm{t} / \mathrm{m}^{3}$, we found that the aboveground biomass of pine trees with DBH of at least $7.0 \mathrm{~cm}$ amounts at the study site to $30.7202 \mathrm{t}$. When using the $\mathrm{BEF}$ index $=1.67$ and wood density of $0.430 \mathrm{t} / \mathrm{m}^{3}$, the aboveground biomass of large pine timber at the study site amounts to 36.630 t. When using Czuraj's tables (1991), the value was $37.868 \mathrm{t}$.

The difference between these two last values is $1.238 \mathrm{t}$, which accounts for $3.27 \%$ of the aboveground biomass determined at the study site using Czuraj's (1991) tables. This 
value is similar to the percentage contribution of needles in the aboveground biomass of pine tree stands quoted in the literature, which is usually not included in the BEF index. For example, Orzeł et al. (2006a) report that the needles account for $3.2 \%$ of the total aboveground biomass of pine tree stands in the Niepołomice Forest. Our analysis shows that the ratio of the total biomass $37.868 \mathrm{t} / \mathrm{m}^{3}$ and the biomass of large (merchantable) timber $21.934 \mathrm{t} / \mathrm{m}^{3}$ of the main tree stand, calculated on the basis of Czuraj's (1991) tables, was 1.726 . The higher value, above 1.67 , may result from the contribution of leaves in the total aboveground biomass of trees.

When using Szymkiewicz's (2001) tables for pine with the site index class Ia based on average DBH and the height of trees, as well as using the biomass extension factor of 1.67 and the wood density index of $0.43 \mathrm{t} / \mathrm{m}^{3}$, the aboveground biomass of the pine forest stand growing over an area of 0.1994 ha was only $29.961 \mathrm{t}$, which is $7.907 \mathrm{t}$ less than the value obtained based on Czuraj's (1991) tables. When using the BEF index of 1.726, the difference was $6.902 \mathrm{t}$.

The biomass assessment accuracy was also affected by adopted values of weight of one individual in the height classes defined every $0.5 \mathrm{~m}$ within the range from 0 to $10.0 \mathrm{~m}$. Direct measurements were used only for the lowest classes of the most abundant species, i.e. pine, birch and black cherry. For higher and thicker specimens of pine and birch, but with DBH below $7.0 \mathrm{~cm}$, values determined for individuals growing at the adjacent sites in 2015 were used. This principle was also applied in the case of rare species (beech, common juniper), usually occurring in lower height classes, to avoid their elimination or reduction of their contribution at the study site. For some species such as beech, spruce, grey alder, literature data were also used.

Factors converting the biomass to wood density also affected the quality of biomass assessment. For the dominant species, i.e. pine and birch, conversion factors of 0.430 and $0.520 \mathrm{t}$ dry matter $/ \mathrm{m}^{3}$ were used (respectively) in the Poland's National Inventory Report (KOBiZE, after Jabłoński \& Budniak, 2014). These values are much lower than those provided by Krzysik (1978): 0.490 t dry matter/ $\mathrm{m}^{3}$ for pine and $0.610 \mathrm{t}$ dry matter $/ \mathrm{m}^{3}$ for birch. The value adopted for pine, i.e. $0.430 \mathrm{t} / \mathrm{m}^{3}$, is also lower than the value of $0.450 \mathrm{t} / \mathrm{m}^{3}$ proposed for pine by Trendelenburg and Mayer-Wegelin (1955). It is, however, similar to the value of $0.435 \mathrm{~kg} / \mathrm{m}^{3}$ determined by Tomczak and Jelonek (2013) based on the analysis of a large material collected in e.g. forest divisions of Trzebielino, Drawsko Pomorskie and Warcino (RDSF Szczecinek) in the Pomerania region and in the Oleśno Forest Division (RDSF Katowice). For pines growing in forested areas, the above authors reported a higher value of $0.478 \mathrm{t} / \mathrm{m}^{3}$. The lower value for pines growing on former agricultural lands is usually explained by their rapid increments (Tomczak et al., 2009). This effect was also confirmed by Helińska-Raczkowska and Fabisiak (1992), who reported that trees characterised by rapid growth (the so-called "wolf trees") are characterised by low average density. For 23-year-old pine trees (i.e. of a similar age as pines growing in our study area), the authors determined that the default wood density is in the range of $0.321-0.360 \mathrm{t} / \mathrm{m}^{3}$.

On the other hand, other authors found (though based on less extensive material) that the default value for wood density of pine on former agricultural lands is higher compared to forested lands. For example, based on the research conducted in the Miastko Forest Division (RDSF Szczecinek), thus near the areas managed by the Przymuszewo Forest Division, Jelonek et al. (2009) found that wood of trees growing on the habitat of fresh coniferous forest (on ancient forest soils) was characterised by average default density of $0.4257 \mathrm{t} / \mathrm{m}^{3}$, while trees growing on former agricultural lands $-0.47046 \mathrm{t} / \mathrm{m}^{3}$. On a slightly more fertile habitat of fresh mixed coniferous forest, the wood density was at the level of $0.43413 \mathrm{t} / \mathrm{m}^{3}$ on ancient forest soils and $0.47407 \mathrm{t} / \mathrm{m}^{3}$ on a former agricultural land. Furthermore, the above authors found that wood density depends on the biosocial class of trees. In the case of trees growing on former arable lands, wood of predominant trees (Kraft class I) is characterised by the highest density $-0.50561 \mathrm{t} / \mathrm{m}^{3}$, while the wood of codominant trees (Kraft class III) - by the lowest density of 0.44848 $\mathrm{t} / \mathrm{m}^{3}$. The wood of dominant trees (Kraft class II) has an average density of $0.45135 \mathrm{t} / \mathrm{m}^{3}$. In the case of trees growing on typical forested lands (no agricultural use in the past), codominant trees (class III) are characterised by the highest wood density $-0.44994 \mathrm{t} / \mathrm{m}^{3}$ and the dominant trees (class II) - by the lowest density of $0.42073 \mathrm{t} / \mathrm{m}^{3}$. The wood of predominant trees (class I) has a medium density of $0.42671 \mathrm{t} / \mathrm{m}^{3}$.

According to Jelonek et al. (2010), basic density of wood on the habitat of fresh coniferous forest on typical forest soils is $0.43026 \mathrm{t} / \mathrm{m}^{3}$, whereas on former arable soils $-0.47231 \mathrm{t} / \mathrm{m}^{3}$, with the average general value of $0.45070 \mathrm{t} / \mathrm{m}^{3}$.

Witkowska and Lachowicz $(2012,2013)$ determined that pine in age class II, growing on the habitat of fresh mixed coniferous forests in the Tuchola Forest, is characterised by the default wood density of $0.419 \mathrm{t} / \mathrm{m}^{3}$ at $\mathrm{DBH}$, $0.382 \mathrm{t} / \mathrm{m}^{3}$ halfway up the trunk, and $0.375 \mathrm{t} / \mathrm{m}^{3}$ in the upper end of merchantable timber. Based on the analysis of 400 samples of trees from four regions of Poland, growing on four types of habitats (DCF - dry coniferous forest, FCF - fresh coniferous forest, FMCF - fresh mixed coniferous forest, FMF - fresh mixed forest) and representing four age classes (from II to IV) and three different heights of the trunk, the above authors arrived at an average value of $0.417 \mathrm{t} / \mathrm{m}^{3}$. The default value of wood density for the Tuchola Forest region, in the same range of habitat types, 
age classes and trunk heights, was $0.420 \mathrm{t} / \mathrm{m}^{3}$, which is similar to the value of $0.430 \mathrm{t} / \mathrm{m}^{3}$ used in our calculations.

Biomass density of Scots pine wood also depends on its maturity and varies along the position of the cross-section on the longitudinal stem profile. Based on the analysis carried out in six pine forest stands on the habitat of fresh coniferous forest and fresh mixed coniferous forests, Tomczak and Jelonek (2012) determined that the default density of young and mature wood decreases with increasing distance from the base of the trunk. At the breast height and in the middle of the section between DBH and the base of the live crown, the density of juvenile wood was lower compared to mature wood. At the base of the live crown, juvenile wood was characterised by a higher density, but the differences were not statistically significant. For all samples collected at three heights of trees growing at six sites in two types of forest habitat, the above authors arrived at a density of $0.396 \mathrm{t} / \mathrm{m}^{3}$ for juvenile wood and $0.423 \mathrm{t} / \mathrm{m}^{3}$ for mature wood. Taking into account the effect of spacing and arrangement of seedlings in plantations of Scots pine harvested for construction timber as defined by Spława-Neyman et al. (1995), one can assume that artificially regenerated forest stands (i.e. developed from planting), usually having a greater density and more regular distribution of trees, are characterised by a higher proportion of mature wood, which results in higher wood density (Tomczak \& Jelonek, 2012; Jabłoński \& Budniak, 2014). For this reason, the value of $0.423 \mathrm{t} / \mathrm{m}^{3}$, similar to the conversion factor of $0.430 \mathrm{t} / \mathrm{m}^{3}$ used in our studies, appears to be more relevant to our study area.

The adopted value of the $\mathrm{R} / \mathrm{S}$ index, i.e. 0.2224 , also affected the biomass assessment. This value indicates that underground parts account for $18.195 \%$ and aboveground parts - for $81.805 \%$ of the total biomass of the forest stand. The value of $18.195 \%$ for pine stands is therefore higher than $14 \%$ quoted by Laurow (1966).

The adopted value is lower than 0.26 obtained by Xiao and Ceulemans (2004) for 10-year-old pine trees, with underground parts accounting for $20.557 \%$ and aerial parts for $79.443 \%$. Xiao et al. (2003) suggested R/S = 0.1442 for 73 -year-old pine, which means that the aboveground part accounted for $87.4 \%$ and the underground part only $12.6 \%$ of the total biomass. Oleksyn et al. (1999) reported $\mathrm{R} / \mathrm{S}=0.2831$ for 12 -year-old pine (underground $22.07 \%$ and aboveground $77.93 \%$ of the total biomass of a tree). Cannell (1982) in his book "World Forest Biomass and Primary Production Data" provided R/S $=0.1985$ for a 22-year-old Pinus nigra Arn. stand in the Netherlands and 0.2577 for a 33-year-old Pinus sylvestris forest stand. The former value is similar to $\mathrm{R} / \mathrm{S}$ equal to 0.2 , proposed by the committee on climate change (IPCC, 1996) for coniferous forests in the temperate zone. Cairns et al. (1997) suggest the value of 0.26 , thus the same as proposed by Xiao and Ceulemans (2004). Kröner (1994) suggests the value of 0.24 . The value of 0.2224 is thus an intermediate value in the range of $0.1442-0.2831$.

Based on the data provided by Cannell (1982), the R/S value for a 42-year-old Betula verrucosa stand in the Moscow Province is 0.207 and for a 35 -year-old forest stand of B. verrucosa and Populus sp. in the region of Novosibirsk -0.2591 . For a silver birch forest stand in the UK, the above values of underground and aboveground biomass yielded the $\mathrm{R} / \mathrm{S}$ value of 0.272 . For birch trees with $\mathrm{DBH}$ of $7 \mathrm{~cm}$ and more, the value of 0.253 was used, and for deciduous trees with DBH below $7 \mathrm{~cm}-0.25$. Bardulis et al. (2015) reported that for young grey alder stands under 10 years of age growing on abandoned agricultural lands in Central Latvian lowlands, the average ratio of the aboveground biomass to roots is $3: 1$. Similar data were provided by Uri et al. (2002, 2007) for grey alder and silver birch in Estonia.

The values obtained for the aboveground biomass (139.256 t/ha) and for the underground biomass (31.545 t/ ha) of the studied forest stand are similar to those quoted in the literature for similar ecological systems. According to Bijak and Zasada (2007), the aboveground biomass for a 23-year-old pine tree stand on the habitat of fresh mixed coniferous forest in the Lubsko Forest Division (RDSF Zielona Góra) is $141.428 \mathrm{t} / \mathrm{ha}$, while for a 34-year-old pine wood in the habitat of fresh coniferous forest in the same forest division - $169.770 \mathrm{t} / \mathrm{ha}$. The average biomass of roots in Lubusz Pine Forests calculated based on the $\mathrm{R} / \mathrm{S}$ ratio was $30.062 \mathrm{t} /$ ha (Bijak \& Zasada, 2007). Values for the biomass of roots in young and middle-aged forest stands were similar: 26.577 and $27.201 \mathrm{t} /$ ha, respectively. They were much lower compared to the oldest forest stands $-36.408 \mathrm{t} / \mathrm{ha}$. In terms of habitat, values of the underground biomass of trees increased with increasing moisture content and habitat fertility: $33.626 \mathrm{t} / \mathrm{ha}$ on the habitat of fresh coniferous forest and $34.111 \mathrm{t} / \mathrm{ha}$ on the habitat of fresh mixed coniferous forests.

The biomass value stated for our study site is also similar to the value obtained by Cannell (1982) for a 33-yearold pine forest stand in the UK. According to this source, the value of aboveground biomass was $140.1 \mathrm{t} / \mathrm{ha}$ and of the underground biomass $-36.1 \mathrm{t} / \mathrm{ha}$, which gives a total value of $176.2 \mathrm{t} / \mathrm{ha}$. Whereas Johansson (1999) reported that aboveground biomass of a 26-year-old silver birch stand growing on fallow lands in Sweden at a latitude of $60^{\circ} 09^{\prime}$ was $175.3 \mathrm{t} / \mathrm{ha}$.

Assuming that carbon accounts on average for $50 \%$ of dry plant matter (Whittaker \& Likens, 1973; Ajtay et al., 1979; Dewar \& Cannell, 1992; Hollinger et al., 1993; Houghton, 1996; Karjalainen, 1996; Gower et al., 2001; Jagodziński et al., 2012; Wysocka-Fijorek \& Zając, 2016), plant biomass at the study site contained ca. $86.592 \mathrm{t}$ $\mathrm{C} / \mathrm{ha}$. When assessing the environmental effects of afforestation on former arable lands implemented in terms of 
greenhouse effect mitigation, the current biomass of a forest community can be compared to the plant biomass of a field existing and cultivated before the afforestation. If the maximum plant biomass before the afforestation of fallow lands was $4.566 \mathrm{t} / \mathrm{ha}$ (as noted in our previous studies conducted in the vicinity of the study area), this value was near 38 times smaller than the biomass recorded in the current forest phase. On the other hand, if it is assumed that the biomass on the field with grain growing was only $3.421 \mathrm{t} / \mathrm{ha}$, this value was more than 50 times smaller than the biomass in the 25 -year-old pine-birch stand. In relation to the maximum biomass reached by the rye field during 25 years, the value was $85.525 \mathrm{t} /$ ha for 25 years, which is only slightly less than half $(49.384 \%)$ of $173.184 \mathrm{t} /$ ha plant biomass in the current forest phase. Similarly, carbon contained in the plant biomass of the field accounts for nearly $50 \%$ in relation to carbon contained in plant biomass of the studied forest ecosystem.

Given the amount of carbon accumulated in plant biomass, afforestation of agricultural lands brings beneficial effects. However, for the entirely objective assessment of the rationality behind such measures, analysis of expenditures and profits should also be carried out in energy and financial units.

\section{References}

Ajtay G.L., Ketner P. \& Duvigneaud P., 1979, Terrestrial primary production and phytomass, [in:] B. Bolin, E.T. Degens, S. Kempe (eds), The Global Carbon Cysle. Wiley, New York: 129-182.

Barcikowski A. \& Loro P.M., 1995, Biomasa igliwia oraz cechy dendrometryczne samosiewów sosny (Pinus sylvestris L.) młodszych klas wieku, rozwijającej się na siedlisku boru świeżego [Needle Biomass and Dendrometrical Features of Scots pine (Pinus sylvestris L.) Natural Regeneration Seedlings of Younger Age Classes, Growing on a Fresh Coniferous Forest Site]. Sylwan CXXXIX (2): 53-62.

Bardulis A., Lazdina D., Daugaviete M., Bardule A., Daugavietis U. \& Rozitis G., 2015, Above ground and below ground biomass in grey alder Alnus incana (L.) Moench. Young stands on agricultural land in central part of Latvia. Agronomy Research 13(2): 277-286.

Bernadzki E., 1990, Koncepcja hodowli lasu na gruntach porolnych [Concepts of silviculture on post-agricultural lands]. Sylwan CXXXIV(3-12): 51-59.

Bernadzki E. \& Kowalski M., 1983, Brzoza na gruntach porolnych [Birch on post-agricultural land]. Sylwan CXXVII(12): 33-41.

Bijak S. \& Zasada M., 2007, Oszacowanie biomasy korzeni w drzewostanach sosnowych Borów Lubuskich
[Assessment of the belowground biomass in Scots pine stands of Bory Lubuskie]. Sylwan 151(12): 21-29.

Cannell M.G.R., 1982, World Forest Biomass and Primary Production Data. Academic Press, A subsidiary of Harcourt Brace Jovanovich Publishers, London New York Paris San Diego San Francisco São Paulo Sydney Tokyo Toronto.

Cairns M.A., Brown S., Helmer E. H. \& Baumgardner G.A., 1997, Root biomass allocation in the world's upland forests. Oecologia 111: 1-11.

Choiński A., 2002, Rzeki Borów Tucholskich (Rivers of the Tuchola Pinewoods], [in:] J. Banaszak, K. Tobolski (eds), Park Narodowy Bory Tucholskie na tle projektowanego rezerwatu Biosfery [Tuchola Forest National Park]. Wydawnictwo Homini, Charzykowy: 139-150.

Czuraj M., 1991, Tablice miąższości kłód odziomkowych i drzew stojących, [Timber volume tables for butt logs and standing trees]. PWRiL: na zlec. Naczelnego Zarządu Lasów Państwowych [PWRiL: commissioned by the Executive Board of State Forests], Warszawa.

Deptuła M., 2004, Influence of changes in the land use on carbon accumulation in the landscape, $\mathrm{PhD}$ Thesis. NCU, Toruń.

Deptuła M., 2006, Influence of the past economy on the structure, carbon accumulation and species diversity of forest stands and phytocenoses. Ecological Questions 7: 57-68.

Dewar R.C. \& Cannell M.G.R., 1992, Carbon sequestration in the trees, product and soils of forest plantations: an analysis using U.K. examples. Tree Physiology 11: 49-71.

Dykiert E., 2000, Zmiany struktury i stanów biomasy zbiorowisk roślinnych $\mathrm{w}$ procesie rozwoju lasu na gruntach porolnych w Zaborskim Parku Krajobrazowym, Praca magisterska [Changes in the structure and biomass of plant communities in the process of forest development on former agricultural lands in $\mathrm{Za}$ borski Landscape Park, Master's thesis]. Uniwersytet Mikołaja Kopernika, Wydział Biologii i Nauk o Ziemi [Nicolaus Copernicus University, Faculty of Biology and Earth Sciences], Torun.

Flinn K.M. \& Vellend M., 2005, Recovery of forest plant communities in post-agricultural landscapes. Frontiers in Ecology and the Environment 3: 243-250.

Gorzelak A., 1999, Zalesianie terenów porolnych [Afforestation of post-agricultural lands]. Instytut Badawczy Leśnictwa, Warszawa.

Gower S.T., Krankina O., Olson R.J., Apps M., Linder S. \& Wang C., 2001, Net primary production and carbon allocation patterns of boreal forest ecosystems. Ecological Applications 11: 1395-1411.

Heil G.W., Muys B. \& Hansen K. (eds), 2007, Environmental Effects of Afforestation in North-Western Eu- 
rope. From field observation to Decision Support. Springer, Dordrecht, The Netherlands.

Helińska-Raczkowska L. \& Fabisiak E., 1992, Zmienność gęstości drewna sosny z drzew należących do grupy tzw. rozpieraczy [Variation of the Scots pine wood density index among so-called wolf trees]. Prace Komisji Technologii Drewna [Studies of Wood Technology Committee] 13: 41-49.

Hollinger D.Y., Maclaren J.P., Beets P.N. \& Turland J., 1993, Carbon sequestration in New Zealand's plantation forests. New Zealand Journal of Forestry 23: 194-208.

Houghton R.A., 1996, Converting terrestrial ecosystems from sources to sinks of carbon. Ambio 25: 267-272.

IPPC, 1996, IPCC Guidelines for National Greenhouse Gas Inventories: Reference Manual.

Jabłoński M. \& Budniak P., 2014, Szacowanie nadziemnej biomasy drzewnej lasów w Polsce na potrzeby sprawozdawczości EKG/FAO i UNFCCC [Estimating above-ground woody biomass of forests in Poland for UNECE/FAO and UNFCCC reporting]. Leśne Prace Badawcze (Forest Research Papers) 75(3): 277-289.

Jagodziński A., M., Jarosiewicz G., Karolewski P. \& Oleksyn J., 2012, Zawartość węgla w biomasie pospolitych gatunków krzewów podszycia leśnego [Carbon concentration in the biomass of common species of understory shrubs]. Sylwan 156(9): 650-662.

Jarzębski M., Nienartowicz A., Deptuła M., Bubnicki J. \& Domin D.J., 2010, Past, current and potential resources of carbon and above-ground plant biomass in the landscape with heats in Tuchola Forest. Ecological Questions 13: 9-27.

Jelonek T., Pazdrowski W. \& Tomczak A., 2009, Właściwości drewna sosny zwyczajnej (Pinus sylvestris L.) na gruntach porolnych w północnej Polsce [Selected properties of wood in Scots pine (Pinus sylvestris L.) growing on post-agricultural land in northern Poland]. Leśne Prace Badawcze (Forest Research Papers) 70(3): 277-286.

Jelonek T., Pazdrowski W., Arasimowicz-Jelonek M. \& Tomczak A., 2010, Właściwości drewna sosny zwyczajnej (Pinus sylvestris L.) pochodzącej z gruntów porolnych [Properties of Wood of Scots pine (Pinus sylvestris L.) growing on former farmlands]. Sylwan 154(5): 299-311.

Johansson T., 1999, Biomass equations for determining fractions of pendula and pubescent birches growing on abandoned farmland and some practical implications. Biomass and Bioenergy 16: 223-238.

Johansson T., 2007, Biomass production and allometric above- and below-ground relations for young birch stands planted at four spacings on abandoned farmland. Forestry 80(1): 41-52.
Johnson W.C. \& Sharpe D.M., 1983, The ratio of total merchantable forest biomass and its applicationto the global carbon budget. Can. J. For. Res. 13: 372-383.

Johnston M.H., Homann P. S., Engstrom J.K., Grigal D.F., 1996. Changes in ecosystem carbon storageover 40 years on an old-field / forest landscape in east-central Minnesota. Forest Ecologyand Management 83: 17-26.

Karjalainen T., 1996, Model computations on sequestration of carbon in managed forests and wood products under changing climatic conditions in Finland. Journal of Environmental Management 47: 311-328.

Kirkby K.J. \& Watkins Ch, 2008, The Ecological History of European Forests. CABI Publishing, CPI Anthony Rowe, Eastbourne.

Kovach W.L., 1993, MVSP - A Multi-Variate Statistical Package for IBM PC's, version 2.1. Kovach Computing Services, Pentraeth, Wales, UK.

Kozakiewicz P., 2010, Czeremcha amerykańska (Prunus serotina Ehrh.) - drzewo z Ameryki Północnej [Black cherry (Prunus serotina Ehrh.) - a tree from North America]. Przemysł Drzewny [Wood Industry] LXI (4): 37-40, Wydawnictwo Świat.

Kröner C., 1994, Biomass fractionation in plants: a reconsideration of definitions based on plant functions, [in:] J. Roy, E. Garnier (eds), A whole plant perspective on carbon-nitrogen interactions. SPB Academic, Haga: 173-185.

Krzysik F., 1978, Nauka o drewnie [Wood science]. PWN, Warszawa.

Laurow Z., 1966, Kompleksowe użytkowanie arbomasy leśnej [Extensive use of forest tree biomass]. Wydawnictwo Świat, Warszawa.

Murillo-Rodriquez J.C., 1994, The carbon budget of the Spanish forests. Biogeochemistry 24: 1-21.

Murillo-Rodriquez J. C., 1997, Temporal variations in the carbon budget of forest ecosystems in Spain. Ecological Applications 7 (2): 461-469.

Muys B., Lust N. \& Granval P., 1992, Effects of grassland afforestation with different tree species on earthworm communities, litter decomposition and nutrient status. Soil Biology and Biochemistry 24: 1459-1466.

Nienartowicz A., Filbrandt-Czaja A., Deptuła M. \& Boiński M., 1998, Changes in land use and their effect on species diversity and above-ground standing crop in the surroundings of lake Milachowo, [in:] S. Borsuk (ed.), Research of the lakes in national parks and other protected areas, II Int. Scientific Conference. Inst. Wyd. Habitat, Bydgoszcz: 20-31.

Nienartowicz A., Kunz M., Deptuła M. \& Domin D., 2002, Ecological consequences of changes in landscape structure in the neighbourhood of Brusy in $19^{\text {th }}$ and $20^{\text {th }}$ century. Ecological Questions 1: 117-135.

Nienartowicz A., Lewandowska-Czarnecka A., Ortega E., Deptula M., Filbrandt-Czaja A. \& Kownacka M., 
2015, Afforestation of heathlands and its influence on the land cover, accumulation of plant biomass and energy flow in the landscape: An example from Zaborski Landscape Park. Ecological Questions 21: 91-99.

Niziński Z., 1990, Zagospodarowanie i produkcyjność drzewostanów na gruntach porolnych na przykładzie OZLP w Szczecinku [Management and productivity of stands on post-agricultural grounds exemplified by Regional Administration of State Forest in Szczecinek]. Sylwan CXXXIV (3-12): 89-96.

Oleksyn J., Reich P.B., Chalupka W. \& Tjoelken M.G., 1999, Differential above- and below-ground biomass accumulation of European Pinus sylvestris populations in 12-yr-old provenance experiments. Scandinavian Journal of Forest Research 14: 7-17.

Orzeł S., Forgiel M., Socha J. \& Ochał W., 2005, Biomass and Annual Production of Common Alder Stands of the Niepołomice Forest, EJPAU 8(1). www.ejpau.media.pl/ volume 8/issue1/forestry/art-25.html.

Orzeł S., Forgiel M., Ochał W. \& Socha J., 2006a, Nadziemna biomasa i roczna produkcja drzewostanów sosnowych Puszczy Niepołomickiej [Aboveground biomass and annual production in stands of the Niepołomicka Forest]. Sylwan 150(9): 16-32.

Orzeł S., Ochał W., Forgiel M. \& Socha J., 2006b, Biomasa i roczna produkcja drzewostanów dębowych Puszczy Niepołomickiej [Biomass and annual production of oak stands in the Niepołomicka Forest]. Sylwan 150(5): $30-43$.

Plan Urządzania Gospodarstwa Leśnego Nadleśnictwa Przymuszewo na okres 01.01.1999-31.12.2008. RDLP Toruń [State Forest Management Plan for the Przymuszewo Forest Division for the period of 01 Jan. 1999-31 Dec. 2009. RDSF, Toruń].

Rykowski K., 1990, Problemy ochrony lasu na gruntach porolnych [Problems of forest protection on afforested agricultural grounds]. Sylwan CXXXIV(3-12): 75-88.

Salbitano F., (ed.), 1988, Human influence on Forest Ecosystem Development in Europe. Pitagora Editrice, Bologna.

Sobczak R., 1996, O przywracaniu lasów na grunty porolne w Polsce [On Restoration of the Forest on Former Agricultural Waste Land in Poland]. Sylwan CXL, 1996(5): 35-41.

Spława-Neyman S., Pazdrowski W. \& Owczarzak Z., 1995, Biometryczne parametry budowy drewna sosny zwyczajnej (Pinus sylvestris L.) w aspekcie więźby sadzenia upraw [Biometric parameters of the Scots pine (Pinus sylvestris L.) wood in the aspect of initial plantation spacings]. Folia Forestalia Polonica 26: 73-84.

Szujecki A., 1990, Ekologiczne aspekty odtwarzania ekosystemów leśnych na gruntach porolnych [Ecological aspects of re development of forest ecosystems on old farm lands]. Sylwan CXXXIV (3-12): 23-40.
Szymkiewicz B., 2001, Tablice zasobności i przyrostu drzewostanów [Wood yield and volume increment tables]. PWRiL, Warszawa.

Tomczak A. \& Jelonek T., 2012, Parametry techniczne młodocianego i dojrzałego drewna sosny zwyczajnej (Pinus sylvestris L.) [Technical parameters of juvenile and mature wood in Scots pine (Pinus sylvestris L.). Sylwan 156(9): 695-702.

Tomczak A., Pazdrowski W. \& Jelonek T., 2009, Wybrane elementy budowy makrostrukturalnej drewna a dojrzałość sosny zwyczajnej (Pinus sylvestris L.) wyrosłej w warunkach gruntów porolnych [Correlation between selected elements of wood macrostructure and maturity of Scots pine (Pinus sylvestris L.) growing on post-agricultural land]. Leśne Prace Badawcze (Forest Research Papers) 70(4): 373-381.

Tomczak A. \& Jelonek T., 2013, Promieniowa zmienność właściwości drewna sosny zwyczajnej (Pinus sylvestris L.) wyrosłej na gruntach porolnych [Radial variation in the wood properties of Scots pine (Pinus sylvestris L.) grown on former agricultural soil]. Leśne Prace Badawcze (Forest Research Papers) 74(2): 171-177.

Trampler T., Kliczkowska A., Dmyterko E., Sierpińska A. \& Matuszkiewicz W., 1990, Regionalizacja przyrodniczo-leśna na podstawach ekologiczno-fizjograficznych [Nature and forest regionalisation on the ecological and physiographic basis]. PWRiL, Warszawa.

Trendelenburg R., \& Mayer-Wegelin H., 1955. Das Holz als Rohstoff, München.

Tuszyński M., 1990, Właściwości gleb porolnych a gospodarka leśna [Properties of post-agricultural soils and forest economy]. Sylwan CXXXIV(3-12): 41-50.

Uri V., Lohmus K., Ostonen I., Tullus H., Lastik R. \& Vildo M., 2007, Biomass production, foliar and root characteristics and nutrient accumulation in young silver birch (Betula pendula Roth.) stand growing on abandoned agricultural land. European Journal of Forest Research 126: 495-506.

Uri V., Tullus H. \& Lohmus K., 2002, Biomass production and nutrient accumulation in short-rotation grey alder (Alnus incana (L.) Moench) plantation on abandoned agricultural land. Forest Ecology and Management 169: 161-179.

Watkins Ch., 1993 Ecological Effects of Afforestation. Studies in the history and ecology of afforestation in Western Europe. CABI International Redwood Press, Melksham.

Whittaker R.H. \& Likens G.E., 1973, Carbon in the biota, [in:] G.M. Woodwell, E.V. Pecan (eds) Carbon and the Biosphere. U.S. Atomic Energy Comission, Washington DC: 281-302.

Wilkoń-Michalska J., Nienartowicz A., Kunz M. \& Deptuła M., 1999, Old land-use maps as a basis for interpreting 
of the contemporary structure of forest communities in Zabory Landscape Park. Phytocoenosis 11: 139-154.

Witkowska J. \& Lachowicz H., 2012, Analiza zmienności gęstości umownej drewna sosny zwyczajnej (Pinus sylvestris L.) wzdłuż wysokości pnia w zależności od wybranych czynników [Analysis of variation in pure density of Scots pine wood (Pinus sylvestris L.) along a trunk height depending on selected factors]. Przegląd Papierniczy 68(9): 573-578.

Witkowska J. \& Lachowicz H., 2013, Zmienność gęstości umownej drewna sosny zwyczajnej (Pinus sylvestris L.) w zależności od wybranych czynników [Variability of conventional wood density of Scots pine (Pinus sylvestris L.) depending on the selected factors], Sylwan 157(5): 336-347.

Wójcik R., 1996, Sukcesja wtórna na gruntach porolnych [Secondary Succession on Former Agricultural Land]. Sylwan CXL, 1996(8): 63-68.

Wysocka-Fijorek E. \& Zając S., 2016, Wartość wiązanego węgla w drzewostanach sosnowych, [w:] Wycena nieruchomości leśnych i ich funkcjonalnych części [Va- lues of carbon accumulated in Scots pine stands [in:] Economic evaluation of forests and their functional parts, Kołobrzeg, 19-21.10.2016. Zakład Zarządzania Zasobami Leśnymi, Instytut Badawczy Leśnictwa [Department of Forest Resources Management, Institute of Forest Research]. http://www1.up.poznan. $\mathrm{pl} / \mathrm{kel} / \mathrm{sites} /$ default/files/dok_konferencje/6.\%20 WysockaFijorek\%20E.,\%20Zaj\%C4\%85c\%20S.\%20 Warto\%C5\%9B\%C4\%87\%20wi\%C4\%85zanego\%20 w\%C4\%99gla\%20w\%20drzewostanach $\% 20$ sosnowych.pdf [Assessed 24.03.2017].

Xiao C.W. \& Ceulemans R., 2004, Agrometric relationships for below and above-ground biomass of young Scots pines. Forest Ecology and Management 203: 177-186.

Xiao C.W., Curiel Yuste J., Janssens I.A., Roskams P., Nachtergale L., Carrara A., Sanchez B.Y. \& Ceulemans R., 2003, Above- and belowground biomass and net primary production in a 73 -year-old Scots pine forest. Tree Physiology 23: 505-516. 